\title{
DINAMIKA KOMUNITAS TUMBUHAN PADA EKOSISTEM BATAS CAGAR ALAM GUNUNG AMBANG
}

\section{PLANT COMMUNITIES DYNAMICS IN THE LIMIT ECOSYSTEMS OF GUNUNG AMBANG NATURE RESERVE}

\author{
Hendra Amon'), Johny Tasirin²) dan Martina A. Langi2) \\ 1)Dinas Pertanian, Perikanan, Peternakan, Perkebunan, Kehutanan dan Ketahanan Pangan Kota Kotamobagu \\ 2)Fakultas Pertanian Unsrat Manado
}

\begin{abstract}
The purpose of this research to study the dynamics of plant communities in the limit ecosystems of Gunung Ambang Nature Reserve. The method used is placed in a systematic research plots with the help of the transect line. The results showed that in the Gunung Ambang Nature Reserve there are 15 species and 12 families seedling phase, 15 species and 13 families sapling phase, 24 species and 18 families of phase pole, 27 species and 20 families of trees phase, outside there Gunung Ambang Nature Reserve 16 species and 13 families seedling phase, 19 species and 16 families sapling phase, 21 species and 18 families phase of pole, as well as 24 species and 17 families of trees phase. The dominance of the species in the Gunung Ambang Nature Reserve phase seedlings and saplings in nantu (Palaquium obtusifolium) of $40.19 \%$ and $41.79 \%$, phase of pole on forest betel (Piper aduncum) of $61.56 \%$, and the phase of the pecan tree (Aleurites moluccana) amounted to $38.25 \%$, outside the Gunung Ambang Nature Reserve phase of seedlings and saplings in nantu (Palaquium obtusifolium) amounted to $42.72 \%$ and $35.77 \%$, phase of pole on forest betel (Piper aduncum) amounted to $28.21 \%$, the phase of the pecan tree (Aleurites moluccana) of $42.12 \%$. Changes in plant communities on limit ecosystems Gunung Ambang Nature Reserve changes constituent species growth, both in terms of population, the distribution of species and dominance of species in a community.
\end{abstract}

Key words: dynamics, community, plant, limit ecosystem, Gunung Ambang

\begin{abstract}
ABSTRAK
Tujuan penelitian ini untuk mempelajari dinamika komunitas tumbuhan pada ekosistem batas Cagar Alam Gunung Ambang. Metode yang digunakan adalah plot penelitian ditempatkan secara sistematik dengan bantuan garis transek. Hasil penelitian menunjukkan bahwa di dalam Cagar Alam Gunung Ambang terdapat 15 spesies dan 12 famili fase semai, 15 spesies dan 13 famili fase pancang, 24 spesies dan 18 famili fase tiang, 27 spesies dan 20 famili fase pohon, di luar Cagar Alam Gunung Ambang terdapat 16 spesies dan 13 famili fase semai, 19 spesies dan 16 famili fase pancang, 21 spesies dan 18 famili fase tiang, serta 24 spesies dan 17 famili fase pohon. Dominasi spesies di dalam Cagar Alam Gunung Ambang fase semai dan pancang pada nantu (Palaquium obtusifolium) sebesar $40,19 \%$ dan $41,79 \%$, fase tiang pada sirih hutan (Piper aduncum) sebesar $61,56 \%$, dan fase pohon pada kemiri (Aleurites moluccana) sebesar 38,25\%, di luar Cagar Alam Gunung Ambang fase semai dan pancang pada nantu (Palaquium obtusifolium) sebesar $42,72 \%$ dan $35,77 \%$, fase tiang pada sirih hutan (Piper aduncum) sebesar $28,21 \%$, fase pohon pada kemiri (Aleurites moluccana) sebesar $42,12 \%$. Perubahan yang terjadi dalam komunitas tumbuhan pada ekosistem batas Cagar Alam Gunung Ambang mengalami perubahan penyusun pertumbuhan spesies, baik dari segi populasi, sebaran spesies maupun dominasi spesies dalam suatu komunitas.

Kata kunci: dinamika, komunitas, tumbuhan, ekosistem batas, Gunung Ambang
\end{abstract}

Eugenia Volume 19 No. 3 Desember 2013 


\section{PENDAHULUAN}

Cagar Alam Gunung Ambang merupakan salah satu kawasan konservasi di Pulau Sulawesi bagian Utara yang terletak pada koordinat antara $0^{\circ}$

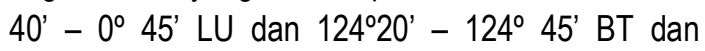
berbatasan dengan Hutan Produksi (HP) dan Hutan Produksi Terbatas (HPT) di sebelah Utara, Kecamatan Modayag di sebelah Selatan, di sebelah Timur dengan Kecamatan Passi Timur, Modoinding dan Tompaso Baru dan sebelah Barat berbatasan dengan Desa Poopoh dan Manembo.

Kawasan Cagar Alam Gunung Ambang dinilai merupakan salah satu kawasan lintas Wallacea yang mempunyai variasi keragaman jenis flora dan fauna ekosistem yang asli. Gopal dan Bhardwaj (1979) menyatakan bahwa keanekaragaman hayati sangat dipengaruhi oleh tipe dan karakteristik suatu ekosistem yang pada gilirannya dipengaruhi oleh sifat organisme, populasi, dan komunitas.

Perubahan fenologi beragam spesies sebagai suatu komunitas akan membawa perubahan terhadap struktur komunitas itu sendiri yang dikenal dengan istilah suksesi (Irwanto, 2006). Di Cagar Alam Gunung Ambang menggambarkan perubahan-perubahan pertumbuhan vegetasi dalam kelompok fungsional tumbuhan. Kelompok fungsional tumbuhan dimaksud adalah pertumbuhan tingkat semai, pancang, tiang, dan pohon. Perubahan dalam komunitas terjadi baik dalam komunitas stabil maupun komunitas yang banyak pembukaan tajuk hutan, seperti pada kawasan yang terambah akibat pembukaan lahan atau menjadi areal peruntukan lain (APL). Kondisi ini dapat mengarah pada perubahan demi perubahan dalam komunitas tumbuhan (Kendeigh, 1980).

Perubahan penyusun pertumbuhan spesies dalam suatu komunitas tumbuhan yang telah dikonversi, areal transisi dan hutan yang memiliki tingkat vegetasi yang rapat, tentunya akan berbedabeda, baik dari segi populasi spesies maupun dominasi spesies dalam suatu komunitas. Spesies yang mendominasi suatu komunitas tumbuhan tergantung pada tipe kawasan hutan diasumsikan berbeda (Gopal dan Bhardwaj, 1979).
Penelitian ini bertujuan untuk mengetahui sebaran spesies dan famili menurut fase tumbuh, mempelajari dominasi spesies dan mengetahui kondisi komunitas tumbuhan pada ekosistem batas Cagar Alam Gunung Ambang.

\section{METODE PENELITIAN}

Penelitian ini dilakukan di dua (2) tipe kawasan pada batas kawasan Cagar Alam Gunung Ambang yaitu kawasan alami (di dalam Cagar Alam) dan kawasan yang yang mengalami gangguan (di luar Cagar Alam). Titik lokasi penelitian pada tipe yang berbeda tersebut berada di arah Desa Tudu Aog, arah Desa Manembo, dan arah Desa Purworejo dari bulan Juli sampai dengan Oktober 2009.

Plot penelitian ditempatkan secara sistematik dengan bantuan garis transek. Variabel pengamatan adalah spesies tumbuhan yang dikelompokkan ke dalam kelompok fungsional yaitu fase semai (seedling), fase pancang (sapling), fase tiang (poles), dan fase pohon (trees).

Lokasi penelitian adalah dua tipe kawasan yaitu kawasan alami dan kawasan yang mengalami gangguan masing-masing dengan radius $150 \mathrm{~m}$ dari batas Cagar. Di setiap tipe kawasan tersebut diambil 3 (tiga) titik yaitu di arah Desa Tudu Aog, Desa Manembo, dan Desa Purworejo membedakan antara dominasi spesies tumbuhan seperti Gambar 1 dan 2.

Lokasi A, Lokasi B, dan Lokasi C pada Gambar 1 masing-masing terdapat di arah Desa Tudu Aog, Desa Manembo, dan Desa Purworejo. Hal-hal yang dapat diperhatikan dalam pengamatan antara lain penentuan garis awal, pembuatan jalur, pembuatan plot pengamatan dan spesimenspesimen yang diamati. Pembuatan jalur transek dimulai pada batas kawasan Cagar Alam Gunung Ambang sebagai titik awal pembuatan jalur. Jalur transek yang akan dibuat adalah berbatasan dengan Cagar Alam. Di dalam jalur transek akan dibuat plot pengamatan, di mana plot tersebut dibuat di dalam dan di luar Cagar Alam. 


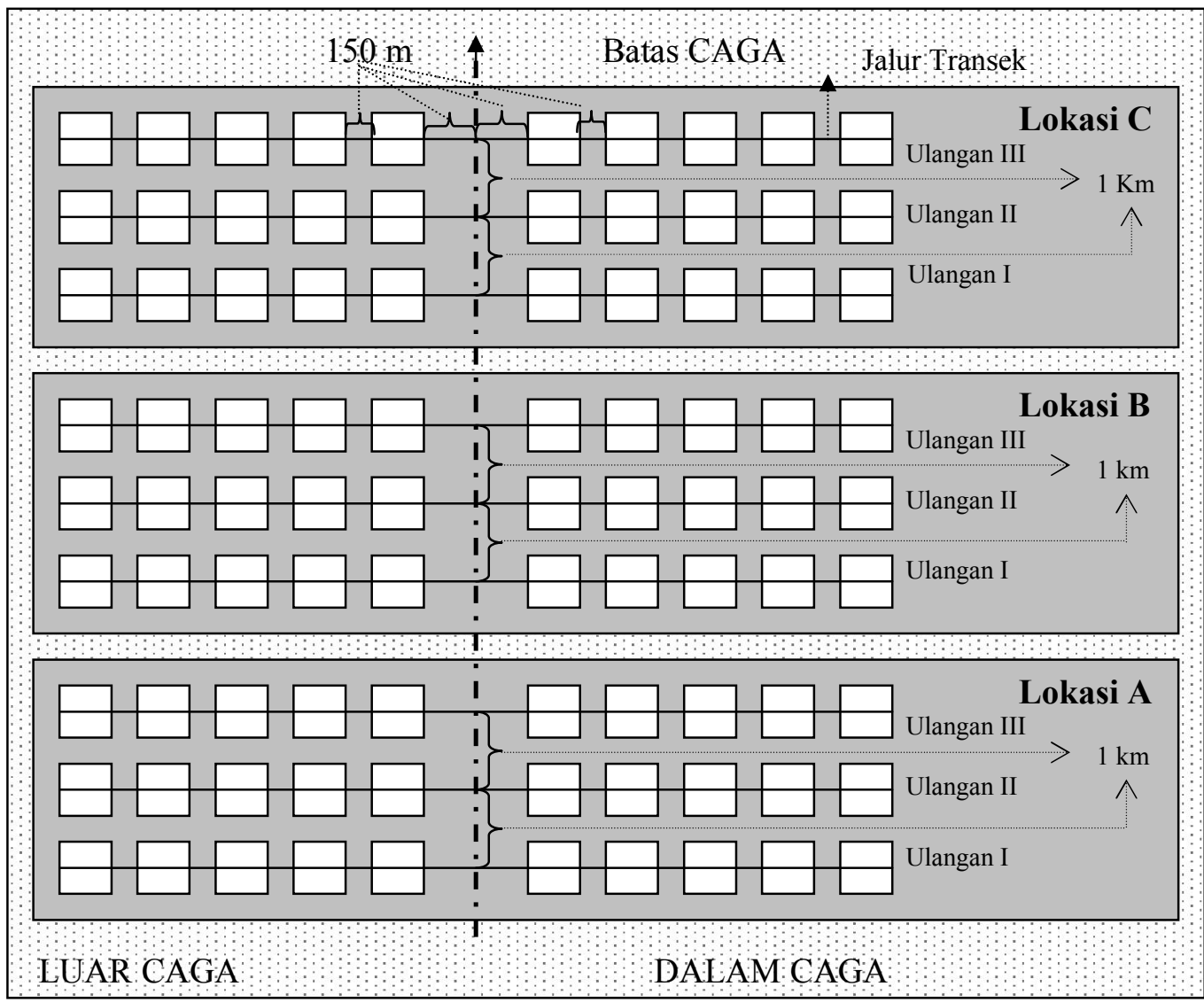

Gambar 1. Model Jalur dan Plot Pada Setiap Lokasi Penelitian.

(Figure 1. Model Plot Line and On Any Location Research)

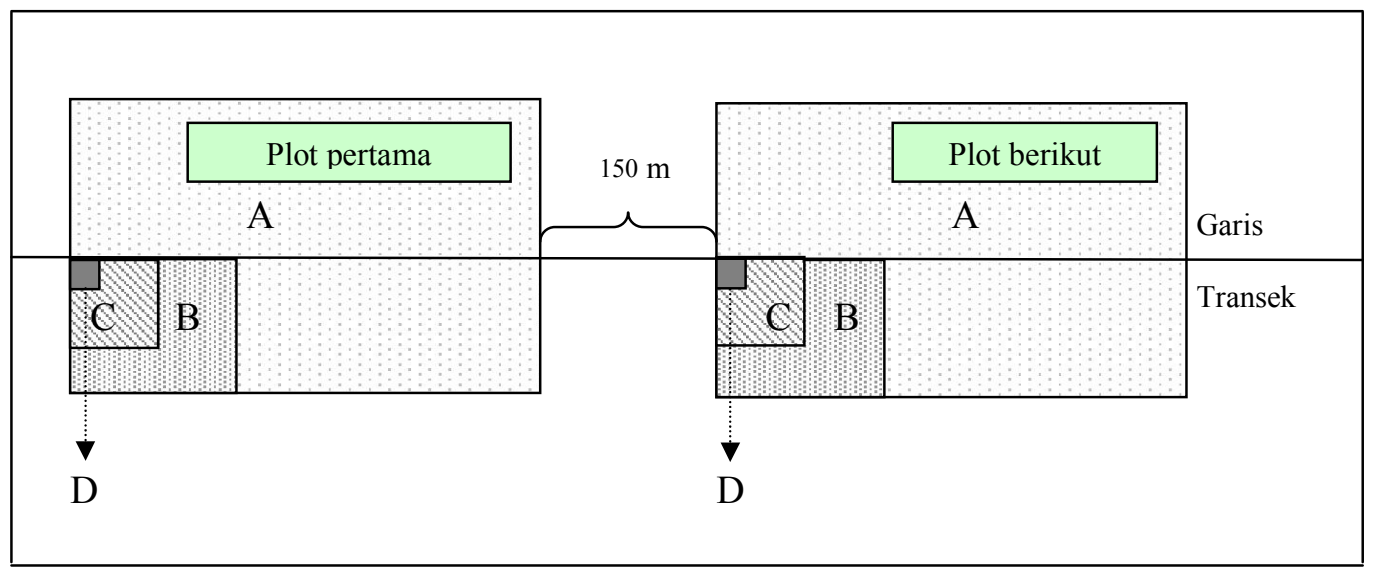

Gambar 2. Desain petak-petak contoh di lapangan dengan metode plot (Kusmana, 1997)

(Figure 2. Design of sample plots in the field with the plot method (Kusmana, 1997))

Gambar 2 menunjukkan pengamatan spesies pada setiap plot. Ukuran plot ditentukan berdasarkan tingkat pertumbuhan spesies tumbuhan. Bentuk dan ukuran plot pengamatan terdiri dari petak A yang berukuran $20 \mathrm{~m} \times 50 \mathrm{~m}$ untuk pengamatan individu fase pohon (trees). 
Petak B dengan ukuran $10 \mathrm{~m} \times 10 \mathrm{~m}$ untuk pengamatan individu fase tiang (poles), petak $\mathrm{C}$ dengan ukuran $5 \mathrm{mx} 5 \mathrm{~m}$ untuk pengamatan individu fase pancang (sapling), dan petak $D$ dengan ukuran $2 \mathrm{~m} \times 2 \mathrm{~m}$ untuk pengamatan individu fase semai (seedling).

\begin{tabular}{|c|c|c|c|}
\hline \multirow{2}{*}{ Kerapatan $(\mathrm{K})$} & \multirow{2}{*}{$=$} & Jumlah suatu individu & \\
\hline & & Luas seluruh petak contoh & \\
\hline Kerapatan Relatif $(K R)=$ & \multirow[b]{2}{*}{$=$} & $\frac{\text { Kerapatan suatu individu }}{\text { Kerapatan seluruh individu }}$ & x $100 \%$ \\
\hline Frekuensi (F) & & \multicolumn{2}{|c|}{$\frac{\text { Jumlah petak contoh ditemukannya suatu individu }}{\text { Luas seluruh petak contoh }}$} \\
\hline Frekuensi Relatif $(F R)=$ & & $\begin{array}{l}\text { Frekuensi suatu individu } \\
\text { Frekuensi seluruh individu }\end{array}$ & x 100\% \\
\hline Dominasi Spesies = & & \multicolumn{2}{|c|}{$\frac{\text { Kerapatan Relatif }+ \text { Frekuensi Relatif }}{2}$} \\
\hline
\end{tabular}

\section{HASIL DAN PEMBAHASAN}

\section{Sebaran Spesies dan Famili Menurut Fase Pertumbuhan}

Jumlah spesies dan famili di dalam CA Gunung Ambang terdapat 15 spesies dan 12 famili fase semai, 15 spesies dan 13 famili fase pancang, 24 spesies dan 18 famili fase tiang, 27 spesies dan 20 famili fase pohon. Sedangkan jumlah spesies dan famili di luar CA Gunung Ambang terdapat 16 spesies dan 13 famili fase semai, 19 spesies dan 16 famili fase pancang, 21 spesies dan 18 famili fase tiang, serta 24 spesies dan 17 famili fase pohon seperti Tabel 1.

\section{Dominasi Spesies pada Ekosistem Batas CA Gunung Ambang. \\ Dominasi Spesies Fase Semai pada Ekosistem Batas CA Gunung Ambang. \\ Tabel 2 menunjukkan bahwa secara rata-} rata, dominasi spesies tertinggi ada pada nantu (Palaquium obtusifolium) sebesar 40,19\%, sedangkan terendah ada pada ceri hutan (Mallotus floribundus), singgolong (Ficus spp), alpokat (Persea americana) dan cempaka hutan (Elmerrilla ovalis) masing-masing sebesar $0,10 \%$. Tabel 3 menunjukkan bahwa secara rata-rata, dominasi spesies
Untuk mengetahui dominasi spesies, maka akan ditentukan dengan besarnya densitas (kerapatan) dan frekuensi suatu spesies tumbuhan. Persamaan yang digunakan berdasarkan rumus dari Soerianegara dan Indrawan (1982), yaitu: 
Tabel 1. Sebaran Spesies dan Famili menurut Fase Pertumbuhan pada Ekosistem Batas Cagar Alam Gunung Ambang

(Table 1. Distribution of Species and Families Growth Phase in the Limit Ecosystems Gunung Ambang Nature Reserve)

\begin{tabular}{|c|c|c|c|c|}
\hline \multirow{3}{*}{ Tingkat Pertumbuhan } & \multicolumn{4}{|c|}{ Tipe kawasan } \\
\hline & \multicolumn{2}{|c|}{ Dalam CA Gunung Ambang } & \multicolumn{2}{|c|}{ Luar CA Gunung Ambang } \\
\hline & Jumlah Spesies & Jumlah Famili & Jumlah Spesies & Jumlah Spesies \\
\hline Semai & 15 & 12 & 16 & 13 \\
\hline Pancang & 15 & 13 & 19 & 16 \\
\hline Tiang & 24 & 18 & 21 & 18 \\
\hline Pohon & 27 & 20 & 24 & 17 \\
\hline
\end{tabular}

Tabel 2. Dominasi Spesies Fase Semai di Dalam Cagar Alam Gunung Ambang (Table 2. Species Dominance of Seedling Phase In Gunung Ambang Nature Reserve)

\begin{tabular}{|c|c|c|c|c|}
\hline \multirow{2}{*}{ No. } & \multicolumn{2}{|r|}{ Spesies } & \multirow{2}{*}{ Famili } & \multirow{2}{*}{$\begin{array}{c}\text { Dominasi } \\
\text { Spesies (\%) }\end{array}$} \\
\hline & Nama Lokal & Nama IImiah & & \\
\hline 1 & Nantu & Palaquium obtusifolium & Sapotaceae & 40,19 \\
\hline 2 & Sirih hutan & Piper aduncum & Piperaceae & 37,66 \\
\hline 3 & Kemiri & Aleurites moluccana & Euphorbiaceae & 10,91 \\
\hline 4 & Dugu'an & Koordersiodendron pinnatum & Anacardiaceae & 5,93 \\
\hline 5 & Jambu Monyet & Eugenia spp & Myrtaceae & 2,88 \\
\hline 6 & Rambutan Hutan & Nephelium lappaceum & Sapindaceae & 1,13 \\
\hline 7 & Matoa & Pometia pinnata & Sapindaceae & 0,40 \\
\hline 8 & Cengkih & Syzygium aromaticum & Myrtaceae & 0,16 \\
\hline 9 & Pala Hutan & Myristica fatua & Myristicaceae & 0,12 \\
\hline 10 & Durian & Durio zibethinus & Bombaceae & 0,12 \\
\hline 11 & Langsat & Aglaia spp & Meliaceae & 0,12 \\
\hline 12 & Ceri hutan & Mallotus floribundus & Euphorbiaceae & 0,10 \\
\hline 13 & Singgolong & Ficus spp & Moraceae & 0,10 \\
\hline 14 & Alpokat & Persea americana & Lauraceae & 0,10 \\
\hline 15 & Cempaka hutan & Elmerrilla ovalis & Magnoliaceae & 0,10 \\
\hline & Jumlah & & & 100 \\
\hline
\end{tabular}

Spesies yang tidak dijumpai di luar CA Gunung Ambang ada pada dugu'an (Koordersiodendron pinnatum), singgolong (Ficus spp) dan angsana (Dalbergia sissoides), sedangkan spesies yang tidak dijumpai di dalam ada pada cengkih (Syzygium aromaticum), dodap (Erythrina variegata), cempaka hutan (Elmerrilla ovalis), mangga (Mangifera indica), kayu kambing (Garuga floribunda), manggis (Garcinia mangostama) dan mahoni (Swietenia macrophylla). 
Tabel 3. Dominasi Spesies Fase Semai di Luar Cagar Alam Gunung Ambang

(Table 3. Species Dominance of Seedling Phase Out Gunung Ambang Nature Reserve)

\begin{tabular}{|c|c|c|c|c|}
\hline \multirow{2}{*}{ No. } & \multicolumn{2}{|r|}{ Spesies } & \multirow{2}{*}{ Famili } & \multirow{2}{*}{ Dominasi Spesies (\% } \\
\hline & Nama Lokal & Nama IImiah & & \\
\hline 1 & Nantu & Palaquium obtusifolium & Sapotaceae & 42,72 \\
\hline 2 & Kemiri & Aleurites moluccana & Euphorbiaceae & 32,61 \\
\hline 3 & Sirih hutan & Piper aduncum & Piperaceae & 15,80 \\
\hline 4 & Langsat & Aglaia spp & Meliaceae & 1,73 \\
\hline 5 & Alpokat & Persea americana & Lauraceae & 1,31 \\
\hline 6 & Dugu'an & Koordersiodendron pinnatum & Anacardiaceae & 1,22 \\
\hline 7 & Rambutan hutan & Nephelium lappaceum & Sapindaceae & 0,77 \\
\hline 8 & Cempaka hutan & Elmerrilla ovalis & Magnoliaceae & 0,77 \\
\hline 9 & Singgolong & Ficus spp & Moraceae & 0,77 \\
\hline 10 & Ceri hutan & Mallotus floribundus & Euphorbiaceae & 0,77 \\
\hline 11 & Cengkih & Syzygium aromaticum & Myrtaceae & 0,37 \\
\hline 12 & Jambu Monyet & Eugenia spp & Myrtaceae & 0,28 \\
\hline 13 & Durian & Durio zibethinus & Bombaceae & 0,28 \\
\hline 14 & Matoa & Pometia pinnata & Sapindaceae & 0,24 \\
\hline 15 & Dodap & Erythrina variegate & Fabaceae & 0,19 \\
\hline 16 & Mahoni & Swietenia macrophylla & Meliaceae & 0,19 \\
\hline \multicolumn{3}{|c|}{ Jumlah } & & 100 \\
\hline
\end{tabular}

Tabel 4. Dominasi Spesies Fase Pancang di Dalam Cagar Alam Gunung Ambang

(Table 4. Species Dominance of Sapling Phase In Gunung Ambang Nature Reserve)

\begin{tabular}{|c|c|c|c|c|}
\hline \multirow{2}{*}{ No. } & \multicolumn{2}{|r|}{ Spesies } & \multirow{2}{*}{ Famili } & \multirow{2}{*}{$\begin{array}{c}\text { Dominasi Spesies } \\
(\%)\end{array}$} \\
\hline & Nama Lokal & Nama IImiah & & \\
\hline 1 & Nantu & Palaquium obtusifolium & Sapotaceae & 41,79 \\
\hline 2 & Sirih hutan & Piper aduncum & Piperaceae & 35,11 \\
\hline 3 & Kemiri & Aleurites moluccana & Euphorbiaceae & 10,22 \\
\hline 4 & Dugu'an & Koordersiodendron pinnatum & Anacardiaceae & 9,29 \\
\hline 5 & Rambutan hutan & Nephelium lappaceum & Sapindaceae & 1,21 \\
\hline 6 & Ceri hutan & Mallotus floribundus & Euphorbiaceae & 0,77 \\
\hline 7 & Jambu Monyet & Eugenia spp & Myrtaceae & 0,68 \\
\hline 8 & Alpokat & Persea americana & Lauraceae & 0,39 \\
\hline 9 & Nangka & Artocarpus integra & Moraceae & 0,09 \\
\hline 10 & Singgolong & Ficus spp & Moraceae & 0,08 \\
\hline 11 & Angsana & Dalbergia sissoides & Papilionaceae & 0,08 \\
\hline 12 & Langsat & Aglaia spp & Meliaceae & 0,08 \\
\hline 13 & Pala hutan & Myristica fatua & Myristicaceae & 0,08 \\
\hline 14 & Durian & Durio zibethinus & Bombaceae & 0,08 \\
\hline 15 & Matoa & Pometia pinnata & Sapindaceae & 0,08 \\
\hline & Jumlah & & & 100 \\
\hline
\end{tabular}




\section{Dominasi Spesies Fase Tiang pada Ekosistem Batas CA Gunung Ambang}

Tabel 6 menunjukkan bahwa secara ratarata, dominasi spesies tertinggi ada pada sirih hutan (Piper aduncum) sebesar 61,56\%, sedangkan terendah ada linggua (Pteocarpus indicus), beringin (Ficus benyamina), amu hutan (Artocarpus communis), nangka (Artocarpus integra) cempaka putih (Ermarrilla celebica), cempaka hutan (Elmerrilla ovalis) dan lamtoro (Leucaena leucephala) masing-masing sebesar 0,09\%. Tabel 7 menunjukkan bahwa secara rata-rata, dominasi spesies tertinggi ada pada sirih hutan (Piper aduncum) sebesar $28,21 \%$, sedangkan terendah ada pada amu hutan (Artocarpus communis), kayu manis (Cinnamomum burmani), jambu biji (Psidium guajava), kayu udun dan singgolong (Ficus spp) masing-masing sebesar $0,11 \%$.

Spesies yang tidak dijumpai di luar ada pada ceri hutan (Mallotus floribundus), matoa (Pometia pinnata), kenari (Canarium spp), angsana (Dalbergia sissoides), kenanga (Cananga odorata), linggua (Pterocarpus indicus), beringin (Ficus benyamina), nangka (Artocarpus integra) dan cempaka putih (Elmerrilla celebica), sedangkan spesies yang tidak dijumpai di dalam CA Gunung Ambang ada pada alpokat (Persea americana), mangga (Mengifera indica), balontang (Crateva nurvala), kayu manis (Cinnamomun burmani), jambu biji (Psidium guajava) dan singgolong (Ficus spp).

\section{Dominasi Spesies Fase Pohon pada Ekosistem Batas CA Gunung Ambang}

Tabel 8 menunjukkan bahwa secara ratarata, dominasi spesies tertinggi ada pada kemiri (Aleurites moluccana) sebesar $38,25 \%$, sedangkan terendah ada pada dodap (Erythrina variegata) dan lamtoro (Leucaena leucephala) masing-masing sebesar $0,08 \%$. Tabel 9 menunjukkan bahwa secara rata-rata, dominasi spesies tertinggi ada pada kemiri (Aleurites moluccana) sebesar $42,12 \%$, sedangkan terendah ada pada pala hutan (Myristica fatua), kayu manis (Cinnamomum burmani), kayu mas (Duabanga moluccana), ketapang (Terminalia catapa) dan kapok (Ceiba petandra) masing-masing sebesar $0,09 \%$.

Tabel 5. Dominasi Spesies Fase Pancang di Luar Cagar Alam Gunung Ambang)

(Table 5. Species Dominance of Sapling Phase Out Gunung Ambang Nature Reserve)

\begin{tabular}{|c|c|c|c|c|}
\hline \multirow{2}{*}{ No. } & \multicolumn{2}{|r|}{ Spesies } & \multirow{2}{*}{ Famili } & \multirow{2}{*}{$\begin{array}{c}\text { Dominasi } \\
\text { Spesies (\%) }\end{array}$} \\
\hline & Nama Lokal & Nama IImiah & & \\
\hline 1 & Nantu & Palaquium obtusifolium & Sapotaceae & 35,77 \\
\hline 2 & Sirih hutan & Piper aduncum & Piperaceae & 25,79 \\
\hline 3 & Kemiri & Aleurites moluccana & Euphorbiaceae & 15,59 \\
\hline 4 & Cengkih & Syzygium aromaticum & Myrtaceae & 4,52 \\
\hline 5 & Langsat & Aglaia spp & Meliaceae & 4,12 \\
\hline 6 & Dodap & Erythrina variegate & Fabaceae & 2,24 \\
\hline 7 & Rambutan hutan & Nephelium lappaceum & Sapindaceae & 2,24 \\
\hline 8 & Jambu Monyet & Eugenia spp & Myrtaceae & 1,53 \\
\hline 9 & Nangka & Artocarpus integra & Moraceae & 1,18 \\
\hline 10 & Cempaka hutan & Elmerrilla ovalis & Magnoliaceae & 1,03 \\
\hline 11 & Durian & Durio zibethinus & Bombaceae & 1,03 \\
\hline 12 & Pala hutan & Myristica fatua & Myristicaceae & 0,93 \\
\hline 13 & Alpokat & Persea americana & Lauraceae & 0,63 \\
\hline 14 & Matoa & Pometia pinnata & Sapindaceae & 0,63 \\
\hline 15 & Mangga & Mangifera indica & Anacardiaceae & 0,63 \\
\hline 16 & Kayu kambing & Garuga floribunda & Burseraceae & 0,63 \\
\hline 17 & Manggis & Garcinia mangostama & Guttiferae & 0,63 \\
\hline 18 & Mahoni & Swietenia macrophylla & Meliaceae & 0,63 \\
\hline 19 & Ceri hutan & Mallotus floribundus & Euphorbiaceae & 0,23 \\
\hline \multicolumn{3}{|c|}{ Jumlah } & & 100 \\
\hline
\end{tabular}


Tabel 6. Dominasi Spesies Fase Tiang di Dalam Cagar Alam Gunung Ambang (Table 6. Species Dominance of Pole Phase In Gunung Ambang Nature Reserve)

\begin{tabular}{|c|c|c|c|c|}
\hline \multirow{2}{*}{ No. } & \multicolumn{2}{|r|}{ Spesies } & \multirow{2}{*}{ Famili } & \multirow{2}{*}{$\begin{array}{l}\text { Dominasi } \\
\text { Spesies (\%) }\end{array}$} \\
\hline & Nama Lokal & Nama IImiah & & \\
\hline 1 & Sirih hutan & Piper aduncum & Piperaceae & 61,56 \\
\hline 2 & Nantu & Palaquium obtusifolium & Sapotaceae & 12,16 \\
\hline 3 & Kemiri & Aleurites moluccana & Euphorbiaceae & 11,14 \\
\hline 4 & Langsat & Aglaia spp & Meliaceae & 4,51 \\
\hline 5 & Rambutan hutan & Nephelium lappaceum & Sapindaceae & 2,33 \\
\hline 6 & Kayu Insil & Trema orientalis & Ulmaceae & 1,85 \\
\hline 7 & Ceri hutan & Mallotus floribundus & Euphorbiaceae & 1,72 \\
\hline 8 & Matoa & Pometia pinnata & Sapindaceae & 0,94 \\
\hline 9 & Durian & Durio zibethinus & Bombaceae & 0,91 \\
\hline 10 & Cengkih & Syzygium aromaticum & Myrtaceae & 0,78 \\
\hline 11 & Kenari & Canarium spp & Burseraceae & 0,46 \\
\hline 12 & Dugu'an & Koordersiodendron pinnatum & Anacardiaceae & 0,42 \\
\hline 13 & Angsana & Dalbergia sissoides & Papilionaceae & 0,13 \\
\hline 14 & Kayu Udun & & & 1,12 \\
\hline 15 & Kenanga & Cananga odorata & Annonaceae & 0,10 \\
\hline 16 & Pinus & Pinus mercusi & Pinaceae & 0,10 \\
\hline 17 & Dodap & Erythrina variegata & Fabaceae & 0,10 \\
\hline 18 & Linggua & Pterocarpus indicus & Papilionaceae & 0,09 \\
\hline 19 & Beringin & Ficus benyamina & Moraceae & 0,09 \\
\hline 20 & Amu hutan & Artocarpus communis & Moraceae & 0,09 \\
\hline 21 & Nangka & Artocarpus integra & Moraceae & 0,09 \\
\hline 22 & Cempaka puth & Elmerrilla cellebica & Magnoliaceae & 0,09 \\
\hline 23 & Cempaka hutan & Elmerrilla ovalis & Magnoliaceae & 0,09 \\
\hline 24 & Lamtoro & Leucaena leucephala & Mimosaceae & 0,09 \\
\hline & Jumlah & & & 100 \\
\hline
\end{tabular}

Tabel 7. Dominasi Spesies Fase Tiang di Luar Cagar Alam Gunung Ambang

(Table 7. Species Dominance of Pole Phase Out Gunung Ambang Nature Reserve)

\begin{tabular}{|c|c|c|c|c|}
\hline \multirow{2}{*}{ No. } & \multicolumn{2}{|r|}{ Spesies } & \multirow{2}{*}{ Famili } & \multirow{2}{*}{$\begin{array}{c}\text { Dominasi } \\
\text { Spesies (\%) }\end{array}$} \\
\hline & Nama Lokal & Nama IImiah & & \\
\hline 1 & Sirih hutan & Piper aduncum & Piperaceae & 28,21 \\
\hline 2 & Kemiri & Aleurites moluccana & Euphorbiaceae & 21,03 \\
\hline 3 & Langsat & Aglaia spp & Meliaceae & 16,36 \\
\hline 4 & Dodap & Erythrina variegata & Fabaceae & 13,88 \\
\hline 5 & Cempaka hutan & Elmerrilla ovalis & Magnoliaceae & 4,14 \\
\hline 6 & Cengkih & Syzygium aromaticum & Myrtaceae & 3,66 \\
\hline 7 & Durian & Durio zibethinus & Bombaceae & 3,38 \\
\hline 8 & Alpokat & Persea americana & Lauraceae & 2,73 \\
\hline 9 & Mangga & Mangifera indica & Anacardiaceae & 1,90 \\
\hline 10 & Nantu & Palaquium obtusifolium & Sapotaceae & 1,41 \\
\hline 11 & Rambutan hutan & Nephelium lappaceum & Sapindaceae & 1,02 \\
\hline 12 & Lamtoro & Leucaena leucephala & Mimosaceae & 0,67 \\
\hline 13 & Kayu Insil & Trema orientalis & Ulmaceae & 0,58 \\
\hline 14 & Dugu'an & Koordersiodendron pinnatum & Anacardiaceae & 0,16 \\
\hline 15 & Balontang & Crateva nurvala & Capparaceae & 0,16 \\
\hline 16 & Pinus & Pinus mercusi & Pinaceae & 0,14 \\
\hline 17 & Amu hutan & Artocarpus communis & Moraceae & 0,11 \\
\hline 18 & Kayu manis & Cinnamomum burmani & Lauraceae & 0,11 \\
\hline 19 & Jambu biji & Psidium guajava & Myrtaceae & 0,11 \\
\hline 20 & Kayu Udun & & & 0,11 \\
\hline 21 & Singgolong & Ficus spp & Moraceae & 0,11 \\
\hline & Jumlah & & & 100 \\
\hline
\end{tabular}


Spesies yang tidak dijumpai di luar Cagar Alam Gunung Ambang ada pada angsana (Dalbergia sissoides), kenari (Canarium spp), singgolong (Ficus spp), kayu macis (Paraserianthes falcataria), linggua (Pterocarpus indicus), sirih hutan (Piper aduncum), kayu Inggris (Eucalyptus spp), eboni (Diospyros spp) dan damar (Agathis alba), sedangkan spesies yang tidak dijumpai di dalam Cagar Alam Gunung Ambang ada pada pinus (Pinus mercusi), pala hutan (Myristica fatua), kayu manis (Cinnamomun burmani), ketapang (Terminalia catapa) dan kapok (Ceiba petandra).

Tabel 8. Dominasi Spesies Fase Pohon di Dalam Cagar Alam Gunung Ambang (Table 8. Species Dominance of Tree Phase In Gunung Ambang Nature Reserve)

\begin{tabular}{rlllr}
\hline \multirow{2}{*}{ No. } & \multicolumn{3}{c}{ Nama Lokal } & \multicolumn{2}{c}{ Nama llmiah } & Famili & $\begin{array}{c}\text { Dominasi } \\
\text { Spesies (\%) }\end{array}$ \\
\cline { 2 - 4 } 1 & Kemiri & Aleurites moluccana & Euphorbiaceae & 38,25 \\
2 & Nantu & Palaquium obtusifolium & Sapotaceae & 29,57 \\
3 & Kayu Insil & Trema orientalis & Ulmaceae & 15,06 \\
4 & Dugu'an & Koordersiodendron pinnatum & Anacardiaceae & 4,26 \\
5 & Ceri hutan & Mallotus floribundus & Euphorbiaceae & 2,85 \\
6 & Alpokat & Persea americana & Lauraceae & 1,30 \\
7 & Cempaka hutan & Elmerrilla ovalis & Magnoliaceae & 1,24 \\
8 & Amu hutan & Artocarpus communis & Moraceae & 1,24 \\
9 & Durian & Durio zibethinus & Bombaceae & 1,06 \\
10 & Langsat & Aglaia spp & Meliaceae & 0,88 \\
11 & Beringin & Ficus benyamina & Moraceae & 0,88 \\
12 & Rambutan hutan & Nephelium lappaceum & Sapindaceae & 0,43 \\
13 & Angsana & Dalbergia sissoides & Papilionaceae & 0,39 \\
14 & Kenari & Canarium spp & Burseraceae & 0,39 \\
15 & Nangka & Artocarpus integra & Moraceae & 0,39 \\
16 & Mangga & Mangifera indica & Anacardiaceae & 0,39 \\
17 & Singgolong & Ficus spp & Moraceae & 0,35 \\
18 & Cengkih & Syzygium aromaticum & Myrtaceae & 0,14 \\
19 & Kayu macis & Paraserianthes falcataria & Mimosaceae & 0,14 \\
20 & Matoa & Pometia pinnata & Sapindaceae & 0,12 \\
21 & Linggua & Pterocarpus indicus & Papilionaceae & 0,10 \\
22 & Sirih hutan & Piper aduncum & Piperaceae & 0,10 \\
23 & Kayu Inggris & Eucalyptus spp & Myrtaceae & 0,10 \\
24 & Eboni & Diospyros spp & Ebenaceae & 0,10 \\
25 & Damar & Agathis alba & Araucariaceae & 0,10 \\
26 & Dodap & Erythrina variegata & Fabaceae & 0,08 \\
27 & Lamtoro & Leucaena leucephala & Mimosaceae & 0,08 \\
\hline & \multicolumn{1}{c}{ Jumlah } & & & 100 \\
\hline
\end{tabular}


Tabel 9. Dominasi Spesies Fase Pohon di Luar Cagar Alam Gunung Ambang

(Table 9. Species Dominance of Tree Phase Out Gunung Ambang Nature Reserve)

\begin{tabular}{|c|c|c|c|c|}
\hline \multirow{2}{*}{ No. } & \multicolumn{2}{|r|}{ Spesies } & \multirow{2}{*}{ Famili } & \multirow{2}{*}{$\begin{array}{c}\text { Dominasi } \\
\text { Spesies (\%) }\end{array}$} \\
\hline & Nama Lokal & Nama IImiah & & \\
\hline 1 & Kemiri & Aleurites moluccana & Euphorbiaceae & 42,12 \\
\hline 2 & Kayu Insil & Trema orientalis & Ulmaceae & 10,29 \\
\hline 3 & Langsat & Aglaia spp & Meliaceae & 9,47 \\
\hline 4 & Dodap & Erythrina variegata & Fabaceae & 8,99 \\
\hline 5 & Cempaka hutan & Elmerrilla ovalis & Magnoliaceae & 7,53 \\
\hline 6 & Durian & Durio zibethinus & Bombaceae & 5,18 \\
\hline 7 & Nantu & Palaquium obtusifolium & Sapotaceae & 3,96 \\
\hline 8 & Manga & Mangifera indica & Anacardiaceae & 3,60 \\
\hline 9 & Alpokat & Persea Americana & Lauraceae & 2,65 \\
\hline 10 & Cengkih & Syzygium aromaticum & Myrtaceae & 1,23 \\
\hline 11 & Rambutan hutan & Nephelium lappaceum & Sapindaceae & 0,93 \\
\hline 12 & Amu hutan & Artocarpus communis & Moraceae & 0,93 \\
\hline 13 & Nangka & Artocarpus integra & Moraceae & 0,81 \\
\hline 14 & Beringin & Ficus benyamina & Moraceae & 0,52 \\
\hline 15 & Lamtoro & Leucaena leucephala & Mimosaceae & 0,52 \\
\hline 16 & Matoa & Pometia pinnata & Sapindaceae & 0,40 \\
\hline 17 & Ceri hutan & Mallotus floribundus & Euphorbiaceae & 0,15 \\
\hline 18 & Pinus & Pinus mercusi & Pinaceae & 0,13 \\
\hline 19 & Dugu'an & Koordersiodendron pinnatum & Anacardiaceae & 0,13 \\
\hline 20 & Pala hutan & Myristica fatua & Myristicaceae & 0,09 \\
\hline 21 & Kayu manis & Cinnamomum burmani & Lauraceae & 0,09 \\
\hline 22 & Kayu mas & Duabanga moluccana & Sonneratiaceae & 0,09 \\
\hline 23 & Ketapang & Terminalia catapa & Combretaceae & 0,09 \\
\hline 24 & Kapok & Ceiba petandra & Bombacaceae & 0,09 \\
\hline & Jumlah & & & 100 \\
\hline
\end{tabular}

\section{Kondisi Komunitas Tumbuhan pada Ekosistem Batas CA Gunung Ambang}

Kondisi komunitas tumbuhan pada ekosistem batas CA Gunung Ambang untuk setiap tingkat pertumbuhan dapat dilihat pada Gambar 3 sampai 6.

Kondisi komunitas tumbuhan pada ekosistem batas CA Gunung Ambang untuk setiap tingkat pertumbuhan berbeda dari aspek keragaman spesies. Keragaman dan populasi spesies tumbuhan di dalam CA Gunung Ambang lebih sedikit daripada di luar CA Gunung Ambang (Gambar 3 dan 4). Hal ini disebabkan bahwa pertumbuhan tingkat semai dan pancang di dalam CA Gunung Ambang tertekan dan tidak mampu berkompetisi dengan spesies lain, sedangkan di luar CA Gunung Ambang disebabkan oleh terbukanya tajuk pohon akibat aktivitas manusia sehingga akan tumbuh spesies-spesies tingkat semai dan pancang karena mendapatkan cahaya matahari dalam pertumbuhannya. Yoza (2009) bahwa spesies yang tidak mendapatkan cahaya matahari dalam hal pertumbuhannya akan sulit untuk tumbuh bahkan tertekan sampai spesies tersebut mati, selain itu sinar matahari turut menentukan jenis vegetasi yang ada.

Keragaman dan populasi spesies tumbuhan di dalam CA Gunung Ambang lebih banyak daripada di luar CA Gunung Ambang (Gambar 5 dan 6). Hal ini disebabkan bahwa pertumbuhan tingkat tiang dan pohon di dalam $\mathrm{CA}$ Gunung Ambang mampu beradaptasi dengan lingkungan, mampu berkompetisi dan memiliki daya tumbuh yang lebih baik dibandingkan dengan 
pertumbuhan spesies lain. Irwan (2009) mengatakan bahwa di dalam masyarakat hutan, sebagai akibat adanya persaingan, jenis-jenis tertentu lebih berkuasa (dominan) daripada jenis lainnya, dominasi suatu spesies disebabkan sepesies tersebut mempunyai daya adaptasi, daya kompetisi dan kemampuan reproduksi yang lebih baik dibandingkan dengan tumbuhan yang lain dalam satu lahan tertentu. Hal yang dapat berpengaruh juga terhadap keberadaan jumlah spesies yang besar karena adanya spesies yang teloran terhadap sinar matahari. Purwaningsih (2005) menyatakan bahwa lebih tingginya jumlah jenis banyak dipengaruhi adanya tumbuhan jenis tertentu yang toleran terhadap sinar matahari. Sedangkan di luar CA Gunung Ambang disebabkan aktivitas manusia sehingga keragaman spesies menurun. Purwaningsih (2005) mengatakan bahwa hutan yang telah mengalami gangguan cenderung memiliki luas bidang dasar (LBD) lebih kecil dan kerapatan pohon lebih tinggi karena banyaknya pohon berukuran kecil.

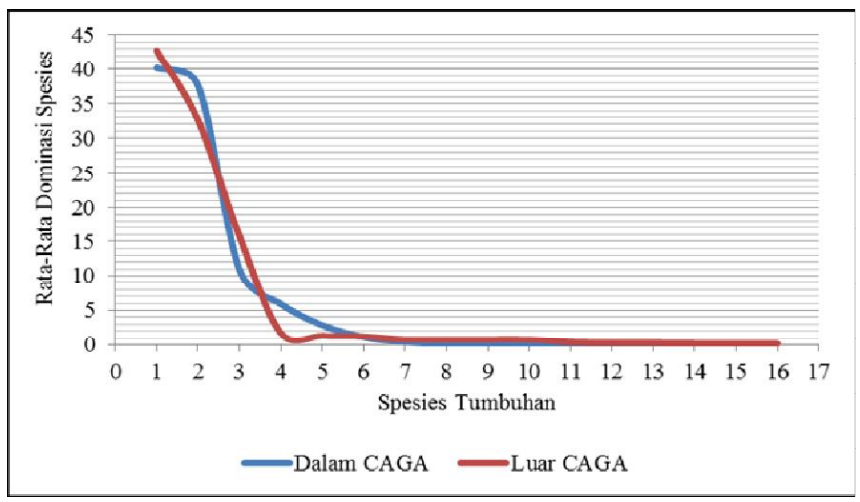

Gambar 3. Kondisi Komunitas Tumbuhan pada Ekosistem Batas CA Gunung Ambang Untuk Pertumbuhan Tingkat Semai

(Figure 3. Condition of Plant Communities in Limit Ecosystem Gunung Ambang Nature Reserve to Growth Seedlings)

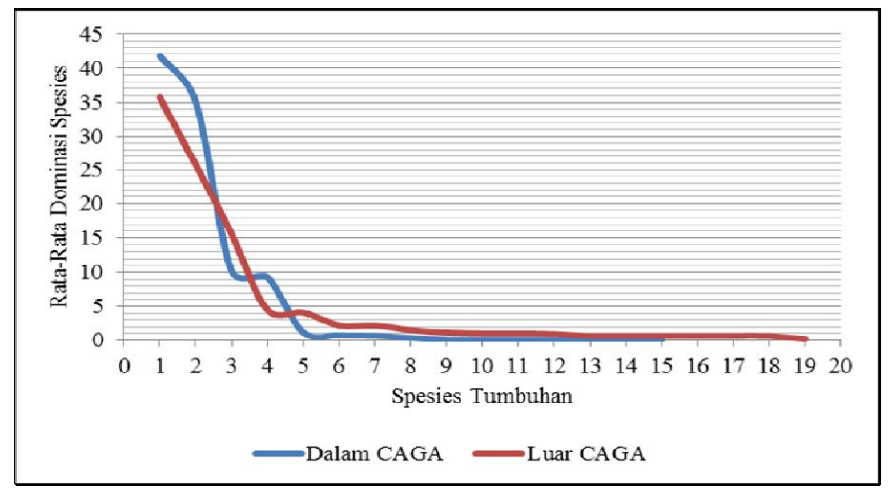

Gambar 4. Kondisi Komunitas Tumbuhan pada Ekosistem Batas CA Gunung Ambang Untuk Pertumbuhan Tingkat Pancang

(Figure 4. Condition of Plant Communities in Limit Ecosystem Gunung Ambang Nature Reserve to Growth Saplings) 


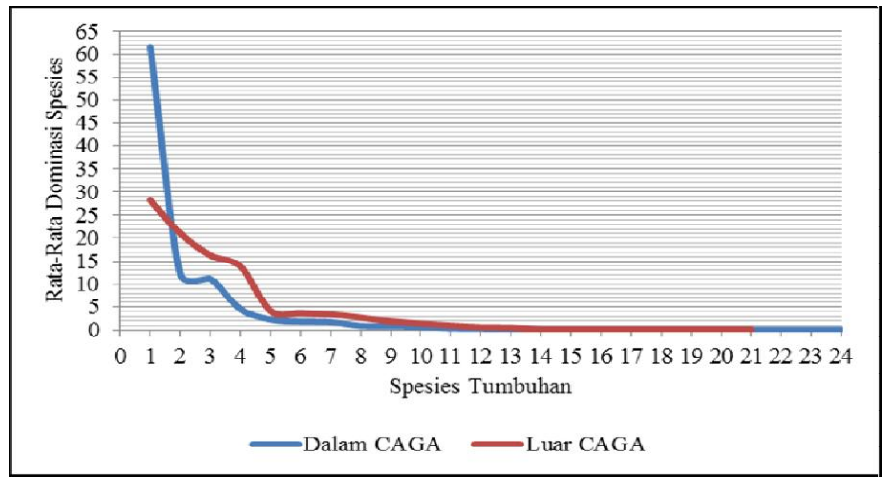

Gambar 5. Kondisi Komunitas Tumbuhan pada Ekosistem Batas CA Gunung Ambang Untuk Pertumbuhan Tingkat Tiang

(Figure 5. Condition of Plant Communities in Limit Ecosystem Gunung Ambang Nature Reserve to Growth Poles)

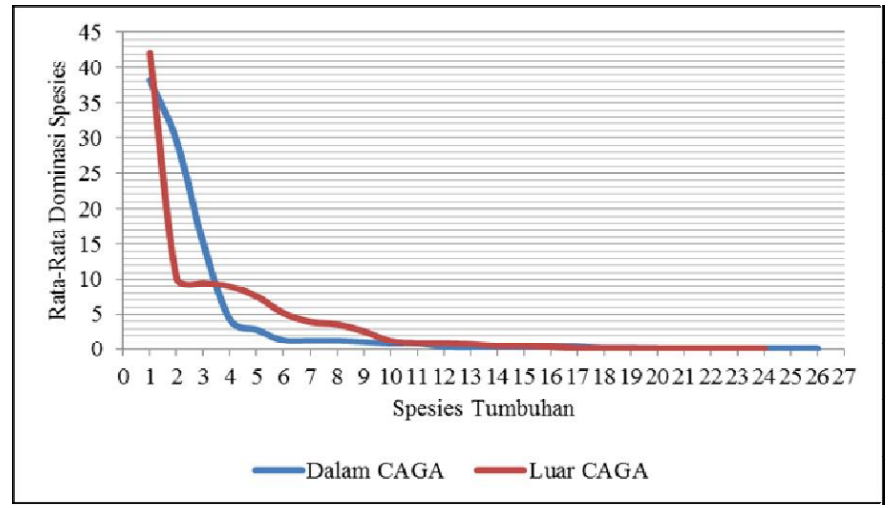

Gambar 6. Kondisi Komunitas Tumbuhan pada Ekosistem Batas CA Gunung Ambang Untuk Pertumbuhan Tingkat Pohon

(Figure 6. Condition of Plant Communities in Limit Ecosystem Gunung Ambang Nature Reserve to Growth Trees)

\section{Dinamika Komunitas Tumbuhan pada Ekosistem Batas CA Gunung Ambang}

Ekosistem batas merupakan kawasan transisi antara kawasan alami (di dalam CA Gunung Ambang) dan kawasan yang telah mengalami gangguan (di luar CA Gunung Ambang. Pada ekosistem batas, sebaran spesies tumbuhan, populasi dan keragaman spesies memiliki kelimpahan spesies yang tinggi dibandingkan pada kawasan lain. Hal yang menjadi ciri khas dari ekosistem batas adalah memiliki sebaran, populasi dan keragaman jenis yang tinggi. Namun, sebaran, populasi dan keragaman jenis mengalami perubahan dalam komunitas tumbuhan apabila ditinjau dari aspek penyusun pertumbuhan spesies ataupun tingkat pertumbuhan.

Perubahan yang terjadi dalam komunitas tumbuhan pada ekosistem batas Cagar Alam Gunung Ambang mengalami perubahan penyusun pertumbuhan spesies, baik dari segi populasi, sebaran spesies maupun dominasi spesies dalam suatu komunitas. Populasi, sebaran dan keragaman spesies pada pertumbuhan semai dan pancang di dalam Cagar Alam menurun dibandingkan di luar 
Cagar Alam, sedangkan populasi, sebaran dan keragaman spesies pada pertumbuhan tiang dan pohon di dalam Cagar Alam meningkat dibandingkan di luar Cagar Alam.

\section{KESIMPULAN}

Sebaran spesies dan famili dalam komunitas tumbuhan pada ekosistem batas CA Gunung Ambang bervariasi. Di dalam CA Gunung Ambang terdapat 15 spesies dan 12 famili fase semai, 15 spesies dan 13 famili fase pancang, 28 spesies dan 18 famili fase tiang, 27 spesies dan 20 famili fase pohon, sedangkan di luar CA Gunung Ambang sebanyak 16 spesies dan 13 famili fase semai, 19 spesies dan 16 famili fase pancang, 21 spesies dan 18 famili fase tiang, 24 spesies dan 17 famili fase pohon.

Dominasi spesies dalam komunitas tumbuhan pada ekosistem batas CA Gunung Ambang fase semai dan pancang ada pada nantu (Palaquium obtusifolium), fase tiang ada pada sirih hutan (Piper aduncum), dan fase pohon ada pada kemiri (Aleurites moluccana).

Kondisi komunitas tumbuhan pada ekosistem batas CA Gunung Ambang berbeda. Tingkat pertumbuhan fase semai dan pancang di dalam CA Gunung Ambang jumlah spesies lebih sedikit daripada pertumbuhan tingkat tiang dan pohon yang merupakan tegakan hutan. Hal ini disebabkan bahwa pertumbuhan tingkat semai dan pancang di dalam CA Gunung Ambang tertekan dan tidak mampu berkompetisi dengan spesies lain, sedangkan di luar CA Gunung Ambang disebabkan oleh terbukanya tajuk pohon akibat aktivitas manusia sehingga akan tumbuh spesies-spesies tingkat semai dan pancang karena mendapatkan cahaya matahari dalam pertumbuhannya. Pertumbuhan tingkat tiang dan pohon di dalam CA Gunung Ambang mampu beradaptasi dengan lingkungan, mampu berkompetisi dan memiliki daya tumbuh yang lebih baik dibandingkan dengan pertumbuhan spesies lain, sedangkan di luar CA Gunung Ambang disebabkan aktivitas manusia sehingga keragaman spesies menurun.

Dinamika yang terjadi dalam komunitas tumbuhan pada ekosistem batas Cagar Alam
Gunung Ambang mengalami perubahan penyusun pertumbuhan spesies, baik dari segi populasi, sebaran spesies maupun dominasi spesies dalam suatu komunitas ditinjau dari tingkat pertumbuhan spesies.

\section{DAFTAR PUSTAKA}

Gopal, B. dan N. Bhardwaj. 1979. Elements of Ecology. Departement of Botany. Rajasthan University Jaipur, India.

Irwan, T. D. 2009. Komposisi Jenis dan Struktur Tegakan Hutan Di Taman Nasional Gunung Ciremai, Jawa Barat. Skripsi. Bogor: Fakultas Kehutanan. Institut Pertanian Bogor.

Irwanto, 2006. Dinamika dan Pertumbuhan Hutan Sekunder. Dalam http://www.irwantoshut. com. Diakses pada 9 Juni 2009 pukul 11:45 WITA..

Kendeigh, S.C. 1980. Ecology with Special Reference to Animal and Man. Departement of Zoology University of Illinois at Urbana-Champaign. New Delhi: Prentice-Hall of India Private Limited.

Kusmana, C. 1997. Metode Survey Vegetasi. PT Penerbit Institut Pertanian Bogor.

Purwaningsih, 2005. Analisis Vegetasi Hutan pada Beberapa Ketinggian Tempat di Bukit Wawouwai, Pulau Wawonii, Sulawesi Tenggara. Bidang Botani, Pusat Penelitian Biologi, Lembaga IImu Pengetahuan Indonesia (LIPI), Bogor 16122. Jurnal Biodiversitas. ISSN: 1412-033X Volume 7, Nomor 1 Januari 2006 Halaman: 49-53.

Soerianegara, I. dan Indrawan. 1982. Ekologi Hutan Indonesia. Bogor. Departemen Manajemen Hutan Fakultas Kehutanan Institut Pertanian Bogor.

Yoza, Defri. 2009. Klimatologi Hutan. Pusat Pengembangan Pendidikan. Pekanbaru. 
